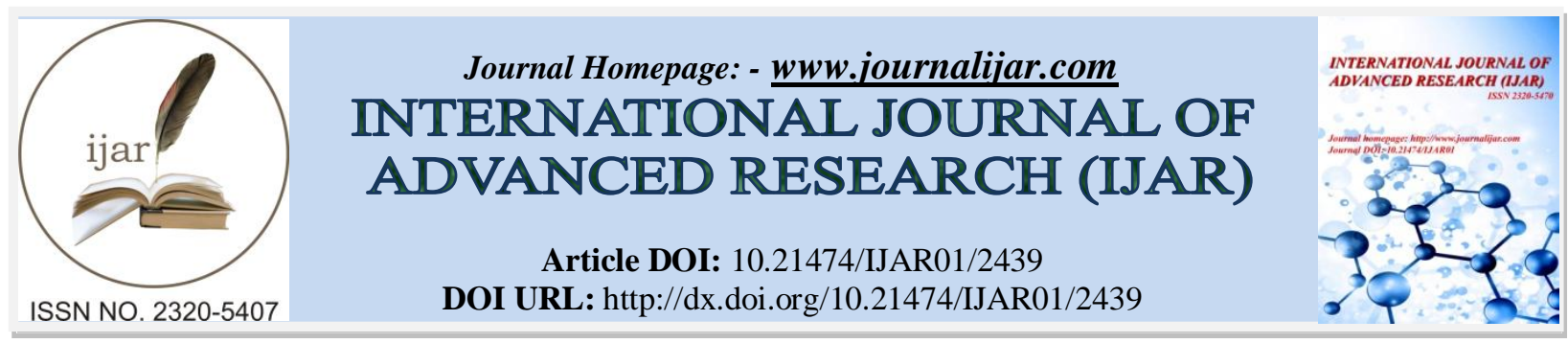

RESEARCH ARTICLE

VIRTUAL KEYBOARD.

\title{
HYGIENIC DETOXIFICATION OF BIOACTIVE AND FUNCTIONAL FOOD CONSTITUENTS OF SOYBEAN [GLYCINE MAX (L.)MERRILL] CULTIVARS.
}

\author{
"Manoj Kumar Pathak ${ }^{1}$, Arun Kakkar' ${ }^{1}$ C.J. Singh ${ }^{2}$, B. K. Dixit ${ }^{2}$ and P.N. Tripathi ${ }^{2}$. \\ 1. Govt. Model Science College (Autonomous), R.D.U. Jabalpur (M.P.) India. \\ 2. JNKVV, Jabalpur (MP) India.
}

\section{Manuscript Info}

Manuscript History

Received: 20 October 2016

Final Accepted: 22 November 2016

Published: December 2016

Key words:- Soybean, trypsin inhibitor, lipoxygenase, peroxidaes, processing, detoxification.

\section{Abstract}

The agriculture produce soybean have phytochemically many constituents of nutraceuticals, and pharmaceutical herbal products. Soybean is known a golden bean because of its miraculous nutritive capacity it contains approximately $38-42$ percent high valued proteins supplies sufficient amount of various kind of amino acids. Oil content ranges from 15-21 percent. Currently worldwide interest is increasing in a trend ready to eat food to achieve the goal for healthcare. The combination of food material constituents may be responsible for biological actions that have been eaten.

High temperature and pressure processing technique based only aqueous steam and time duration factors detoxification of various toxicants and anti- nutritional constituents. This processing technique no unhygienic chemical used or released that may be harmful for environmental pollution. Detoxification process parameters trypsin inhibitor found as specific activity ranged from 220-270 as compared to raw seeds were $930-110$ ( $\mu \mathrm{M}$ tyrosine/min/g protein), lipoxygenase ranged 4936-5502 as compared to raw seeds mean recorded 19053$24167(\mu \mathrm{M}$ hydroperoxide/min/mg protein) and peroxidase enzyme also reduced the specific activity from 1.00-10.00 as compared to raw seeds have 18.249-20.807 (nM hydroperoxide/min/g protein) reduced highly significant as compare to raw seeds mean values of soybean. The processing technique can be established within specified parameters reduced toxic constituents variation as compare to raw material helps to increase consumer's confidence.

Copy Right, IJAR, 2016,. All rights reserved.

\section{Introduction:-}

Soybean [Glycine $\max (\mathrm{L}$.)Merrill] belongs to family fabaceae herbaceous annual of Asiatic origin. Its ranks first among the oil seed crops in the world and India both.Soybean has been adopted and commercially cultivated in Madhya Pradesh, Maharashtra, Rajasthan, Karnataka and Andhra Pradesh. At present, it has been established as a most important oilseed crop of M.P. and India. Gupta, et al. (2014). Soybean has unprecedented expansion in India by recording $15-20 \%$ annual growth rate. It has emerged very fast since early eighty's and occupied vital place in agriculture, edible oil economy, foreign exchange and up liftment of socio-economic status of soybean farmers. It 
contributes around $25 \%$ of total edible oil pool of the country. The credit for such a big boost about 5.20 lacks MT production of soybean in the country goes to Madhya Pradesh popularly known as "Soya bowl" of the country.

Soybeans are good source of vegetable protein used to supplemented animal protein in the vegetarian's diet. It is rich in low cholesterol lipids well known to researchers legumes are good source of fibre content. The process and technology are essential for improving the shelf life of soy products, enhancement of nutritional security almost its quality and safe for uses.

\section{Anti-nutrients and phytochemicals:-}

Soybeans contains various undesirable phytochemicals; anti-nutritional factor one of them principally is trypsininhibitors(TI), which limits straight utilization in food as whole uses of soybean seeds Verma et al. (2015) and Shivakumar et al. (2015) used KTI as genotypes morphomolecular identified for developing cultivars of soybean. Trypsin inhibitor is a antinutritional factor that affects protein digestibility Vineet et al., (2005). High level of trypsin inhibitors in a diet stimulates pancreatic juice secretion, causes pancreatic hypertrophy and poor growth performance in animals announced by Huisman \& Tolman, (2001). Depresses the absorption of minerals, have a negative impact on utilization. The natural toxicant and anti-nutrients have been widely employed to describe plant defense metabolites are limiting factors in the food and nutrition Messina (2004). Seed contain several beneficial phytochemicals essential for growth, development and reproduction Peltier et al.(2009), Olorode et al.(2014). Soy flour, flour fortification, fortification of cereals products is more efficient means of incorporating soy protein in diet for human Liu, (1997), Young, (1997) consumption of soy has been linked to prevention and treatment of chronic disease.

Preoxidase (EC.1.11.1.X) occurs in plants mainly in soybean seed. It is ubiquitous in nature. It catalyze the oxidation of many organic compounds by hydrogen peroxide: animes (o-phenylendiaminne,p-phenlendediamine, benzidine), phenol (pyrogallol, guaicol, o-cresol) hydorquinones, etc. The soybean seed have oxidoreductive peroxidase enzyme belong to class III of the super family phytochemically seed coat content highest activity Ghaemmaghami,et al.(2010).

Peroxidase reaction: $\left[\mathrm{AH}_{2}+\mathrm{H}_{2} \mathrm{O}+\right.$ peroxidase $\rightarrow 2 \mathrm{H}_{2} \mathrm{O}+\mathrm{A}$ ] here, $\mathrm{AH}_{2}$ is a hydrogen donor and $\mathrm{A}$ is its oxidized form. Increases in peroxidase activity have been reported in a number of host-parasitic interactions. The peroxidase activity is the reasably stable to heat that have destroyed all peroxidase activity and usually considered to be more adequate to destroy other enzymes and most microbs.In the processing therefore, the adequacy of the blanching process can be monitored by disappearance of peroxidase activity of seeds USDA,(1975). The oxidation of guaicol (colourless) to forms tetraguaicol and water. Reaction: $\mathrm{H}_{2} \mathrm{O}_{2}+$ Guaicol+Peroxidase $\rightarrow$ Tetra-guaicol (colored) + Water.

The enzyme lipoxygenase (linoleate oxygen oxidoreductase, (EC 1.13.11.12) are dioxigenase that catalyze the hydroperoxidation of polyunsaturated fatty acids containing cis-cis pentadienes [conjugated hydroperoxide derivatives] moieties both linoleic linolenic acids are substrate of lypoxygenase may be a more appropriate enzyme to measure the adequacy of blanching of vegetables than peroxidase of soybeans seed (Marenco et al. (1995), Meriles et al (2000). The enzyme in oil-bearing seeds of soybeans, can be an important source of hydroperoxides formed in the oil during extraction. Lipoxygenase from soybean seed is the best characterized among plant. Lypoxygenase reaction : $\left[-\mathrm{CH}=\mathrm{CH}-\mathrm{CH}_{2}-\mathrm{CH}=\mathrm{CH}-\right)+\mathrm{O}_{2}+$ lypoxygenae $\rightarrow[-\mathrm{COOH}-\mathrm{CH}=\mathrm{CH}-\mathrm{CH}=\mathrm{CH}-]$ (Williams et al. 1986). Soybean seed lipoxygenase catalyses the hydroperoxidation such as linoleic and linolenic acids and enhance the peroxidation of polyunsaturated fatty acids, leading to the production of several reactive molecules that account for the undesirable grassy beany flavor and taste in soybean processed products (Igor, and Svetlana,2008). Biochemically the increasing of oleic acid in oil content also reduced the trypsin inhibitor palmitic, linoleic, and linolenic acid as well as lipoxygenase in soybean seeds Gupta et al. (2014). Its enzymys lypoxygenase produce beany or unacceptable odors, develops the off flavour and which limited their utilization when seeds come contact the water during process.

\section{Materials and methods:-}

The experimental materials are most popular five cultivars of soybean namely as,JS-20-29( $\left.\mathrm{V}_{1}\right), \mathrm{JS}-20-34\left(\mathrm{~V}_{2}\right)$,JS-97$52\left(\mathrm{~V}_{3}\right), \mathrm{JS}-93-05\left(\mathrm{~V}_{4}\right)$ and JS-95-60 $\left(\mathrm{V}_{5}\right)$ were purchased from soybean research unit (BSP),JNKVV, Jabalpur(M.P) 
India. Thermal processing by autoclave cooking for $T_{1 \text { for }} 10$ min., $T_{2 \text { for }} 20 \mathrm{~min}$. and $T_{3}$ for 30 minutes. The raw seeds of each cultivars were also hydroponically germinated $\mathrm{T}_{4}$ in seed germinator at $25-26^{0} \mathrm{C}$ temperature carefully.

For the analysis bioactive, functional phytochemical constituents of each cultivars were dried in hot air oven at 55 ${ }^{0} \mathrm{C}$ for 6-8 hours till the range 5-6\% equilibrium moisture content AOAC (1984) then ground with laboratory hand grinder pack in to plastic air tight container the chemical analysis were carried both raw and processed seeds flour.

\section{Trypsin inhibitor:-}

The trypsin inhibitors activity in soybeans was determined by Keshun Liu and Pericles Markakis, (1989).slightly modified method by Kakade et al (1974), Rackis,(1980), AACC(2000). Protein concentration was determined by modified using standard BSA solution for calibration by Temel (2003).

\section{Lipoxygenase:-}

The method of Axelrod et al. (1981) was followed with a slight modification. The activity of LOX isozyme was determined via the increase in absorbance at $234 \mathrm{~nm}$ after addition of linoleic acid in $0.1 \mathrm{M}$ phosphate buffer $(\mathrm{pH}$ 9.0). Lypoxygenase activity was expressed as an optical density increase per $\mathrm{mg}$ protein/ $\mathrm{min}$.

\section{Peroxidase:-}

Defatted soybean seed flour prepared and used to prepare buffers in accordance with the methods of Gomori,G(1955).The activity of SBP was calculated by Chance and Maehly, (1955).Protein concentration was measured by the modified Lowry method for the protein determination using standard BSA solution for calibration by Temel,(2003).Specific activity by Silva et al.(2000) Ghaemmaghami et al.(2010).

\section{Results and Discussion:-}

Table.1and fig.1 revealed about the effect autoclaved as well as germinated processing techniques on the specific activity for trypsin inhibitor as amount of tyrosine produce per gram protein per minute of each five improved cultivars of soybean seed. The Dunnett's $t$ test for multifactor's comparison was used to identify the significant difference and level of confidence among five cultivars with their (raw seed) control mean.

Table 1:- Specific activity for TIA ( $\mu \mathrm{M}$ tyrosine produced /g. protein $/ \mathrm{min}$ )

\begin{tabular}{|c|c|c|c|c|c|c|}
\hline Treatments & Control & Processed & d value & \multicolumn{3}{|c|}{ Confidence level } \\
\hline V1T1 & 1600 & 940 & -660.000 & -683.417 & to & -636.583 \\
\hline V1T2 & 1600 & 530 & -1070.000 & -1093.417 & to & -1046.583 \\
\hline V1T3 & 1600 & 220 & -1380.000 & -1403.417 & to & -1356.583 \\
\hline V1T4 & 1600 & 490 & -1110.000 & -1133.417 & to & -1086.583 \\
\hline V2T1 & 1200 & 770 & -430.000 & -453.024 & to & -406.976 \\
\hline V2T2 & 1200 & 450 & -750.000 & -773.024 & to & -726.976 \\
\hline V2T3 & 1200 & 240 & -960.000 & -983.024 & to & -936.976 \\
\hline V2T4 & 1200 & 470 & -730.000 & -753.024 & to & -706.976 \\
\hline V3T1 & 1120 & 830 & -290.000 & -316.920 & to & -263.080 \\
\hline V3T2 & 1120 & 410 & -710.000 & -736.920 & to & -683.080 \\
\hline V3T3 & 1120 & 270 & -850.000 & -876.920 & to & -823.080 \\
\hline V3T4 & 1120 & 440 & -680.000 & -706.920 & to & -653.080 \\
\hline V4T1 & 1120 & 890 & -230.000 & -240.833 & to & -219.167 \\
\hline V4T2 & 1120 & 440 & -680.000 & -690.833 & to & -669.167 \\
\hline V4T3 & 1120 & 240 & -880.000 & -890.833 & to & -869.167 \\
\hline V4T4 & 1120 & 500 & -620.000 & -630.833 & to & -609.167 \\
\hline V5T1 & 930 & 910 & -20.000 & -38.730 & to & -1.270 \\
\hline V5T2 & 930 & 380 & -550.000 & -568.730 & to & -531.270 \\
\hline V5T3 & 930 & 220 & -710.000 & -728.730 & to & -691.270 \\
\hline V5T4 & 930 & 460 & -470.000 & -488.730 & to & -451.270 \\
\hline
\end{tabular}




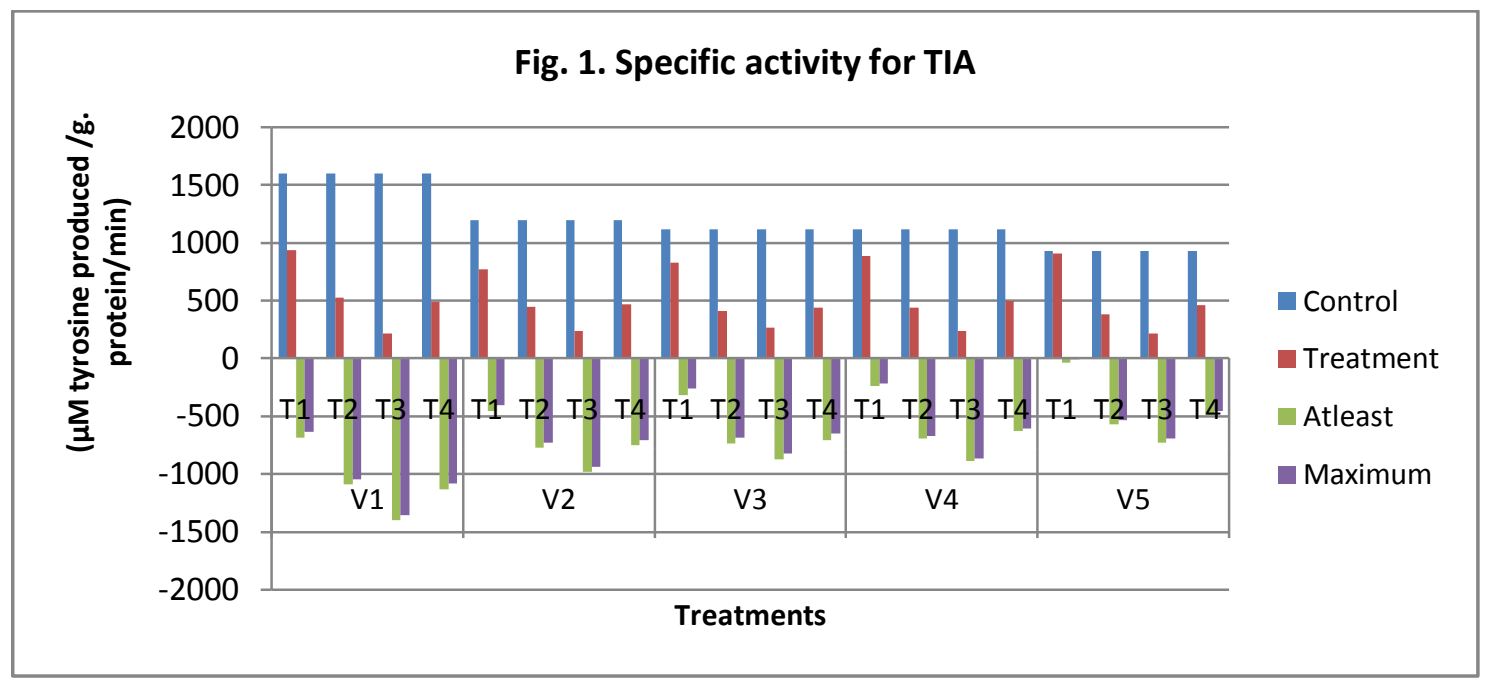

The raw seed of variety $\mathrm{V}_{1}$ recorded significant superior as $1600 \mu \mathrm{M}$ tyrosine produced per gram protein per minute, while $\mathrm{V}_{5}$ showed lowest $930 \mu \mathrm{M}$ tyrosine per gram protein per min. The result indicate that all five varieties differ significantly reduced the specific activity of trypsin inhibitor by the processing on $T_{1}, T_{2}, T_{3}$, and $T_{4}$, as compared with their raw seeds was control. The confidence interval level for treatment $T_{1}, T_{2}$ and $T_{3}$ autoclaved among the variety $\mathrm{V}_{1}$ differ significantly reduced (d value) is highest than $\mathrm{V}_{2}, \mathrm{~V}_{3}, \mathrm{~V}_{4}$, and $\mathrm{V}_{5}$ differ significant with their control. Hence we can say with 95 percent confidence the variety $\mathrm{V}_{1}$ loosed significantly much more activity of trypsin inhibitory on cooking at $\mathrm{T}_{1}, \mathrm{~T}_{2}$, and $\mathrm{T}_{3}$ with their control by at least -683.41 to $-636.58,-1093.41$ to -1046.58 and -14.41 to -13.58 respectively, followed by $V_{2}, V_{4}$ and $V_{3}$ ranged at least -453.02 to -936.97 respectively. The variety $\mathrm{V}_{5} \mathrm{~T}_{3}$ also reduced significant and maintain the quality by at least -728.73 to -691.27 , Messina, M. (2004).

Table. 2 and fig. 2 revealed about the effect autoclaved as well as germinated processing techniques on the specific activity for lypoxygenase as amount of hydroperoxide produce per mg.protein per minute of each five improved cultivars of soybean seed. The raw seed of variety $\mathrm{V}_{5}$ recorded significant superior as $24.17 \mu \mathrm{M}$ hydroperoxide produced per mg. protein per minute, while $\mathrm{V}_{2}$ showed lowest $19.05 \mu \mathrm{M}$ hydroperoxide produced per mg. protein per min. The result indicate that all five varieties differ significantly reduced the specific activity of lypoxygenase by the processing on $T_{1}, T_{2}$ and $T_{3}$, as compare to raw seeds. The confidence interval level for treatment $T_{3}$ among the variety $V_{5}$ differ significantly highest reduced (d value) than $V_{1}, V_{4}, V_{3}$ and $V_{2}$ differ significant with their control mean Marenco, et al.(1995).

Table 2:- Specific activity for lypoxygenase ( $\mu \mathrm{M}$ hydroperoxide/mg protein $/ \mathrm{min}$.)

\begin{tabular}{|c|c|c|c|c|c|c|}
\hline Treatments & Control & Processed & $\mathrm{d}$ value & \multicolumn{3}{|c|}{ Confidence level } \\
\hline V1T1 & 22.3 & 8.66 & -13.640 & -21.755 & to & -5.525 \\
\hline V1T2 & 22.3 & 6.05 & -16.250 & -24.365 & to & -8.135 \\
\hline V1T3 & 22.3 & 3.29 & -19.010 & -27.125 & to & -10.895 \\
\hline V1T4 & 22.3 & 16.06 & -6.240 & -14.355 & to & 1.875 \\
\hline V2T1 & 19.05 & 11.81 & -7.240 & -7.300 & to & -7.180 \\
\hline V2T2 & 19.05 & 6.47 & -12.580 & -12.640 & to & -12.520 \\
\hline V2T3 & 19.05 & 5.39 & -13.660 & -13.720 & to & -13.600 \\
\hline V2T4 & 19.05 & 16.67 & -2.380 & -2.440 & to & -2.320 \\
\hline V3T1 & 22.83 & 10.48 & -12.350 & -12.401 & to & -12.299 \\
\hline V3T2 & 22.83 & 6.49 & -16.340 & -16.391 & to & -16.289 \\
\hline V3T3 & 22.83 & 4.99 & -17.840 & -17.891 & to & -17.789 \\
\hline V3T4 & 22.83 & 19.39 & -3.440 & -3.491 & to & -3.389 \\
\hline V4T1 & 23.87 & 11.28 & -12.590 & -16.601 & to & -8.579 \\
\hline
\end{tabular}




\begin{tabular}{|l|l|l|l|lll|}
\hline V4T2 & 23.87 & 8.1 & -15.770 & -19.781 & to & -11.759 \\
\hline V4T3 & 23.87 & 5.5 & -18.370 & -22.381 & to & -14.359 \\
\hline V4T4 & 23.87 & 22.89 & -0.980 & -4.991 & to & 3.031 \\
\hline & & & & & & \\
\hline V5T1 & 24.17 & 12.01 & -12.160 & -12.169 & to & -12.151 \\
\hline V5T2 & 24.17 & 8.65 & -15.520 & -15.529 & to & -15.511 \\
\hline V5T3 & 24.17 & 5.14 & -19.030 & -19.039 & to & -19.021 \\
\hline V5T4 & 24.17 & 19.41 & -4.760 & -4.769 & to & -4.751 \\
\hline
\end{tabular}

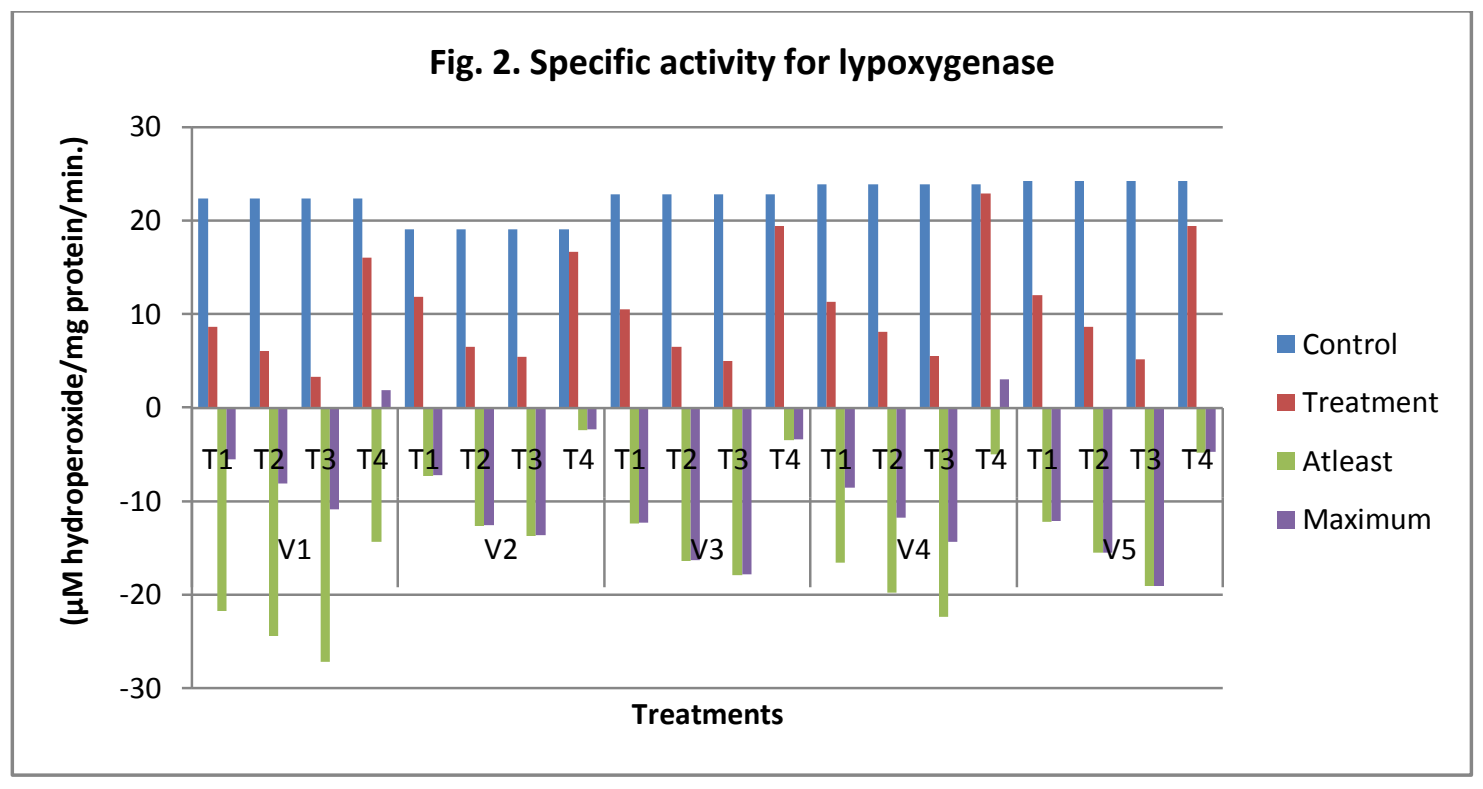

Hence we can say with 95 percent confidence the variety $\mathrm{V}_{5} \mathrm{~T}_{3}$ loosed significantly much more activity of lypoxygenase by at least -19.03 to -19.02 followed by $\mathrm{V}_{1} \mathrm{~T}_{3}-27.12$ to $-10.89, \mathrm{~V}_{4} \mathrm{~T}_{3}-22.38$ to $-14.35, \mathrm{~V}_{3} \mathrm{~T}_{3}-17.89$ to17.78 and $\mathrm{V}_{2} \mathrm{~T}_{3}-13.72$ to -13.60 with their control respectively. We conclude that variety $\mathrm{V}_{5}$ more affected by duration of high temperature and pressure were found to be superior rather than $\mathrm{V}_{2}, \mathrm{~V}_{4}, \mathrm{~V}_{3}$ and $\mathrm{V}_{2}$ respectively with respect losses of lypoxygenase activity as compare with five varieties of raw soybean seeds.

Table. 3 and fig. 3 revealed about the effect autoclaved as well as germinated processing techniques on the specific activity for peroxidase enzyme as amount of hydroperoxide produce per $\mathrm{g}$ protein per minute of each five improved cultivars of soybean seed. The raw seed of variety $\mathrm{V}_{1}$ recorded significant superior as $20.81 \mathrm{nM}$ hydroperoxide produced per mg. protein per minute, while $\mathrm{V}_{2}$ showed lowest $18.25 \mathrm{nM}$ hydroperoxide produced per mg. protein per min. The result indicate that all five varieties differ significantly reduced the specific activity of peroxidase enzyme by the processing on $T_{1}, T_{2}, T_{3}$ and $T_{4}$ as compare to raw seeds. The confidence interval level for treatment $T_{3}$ among the variety $V_{1}$ differ significantly highest reduced (d value) than $V_{5}, V_{4}, V_{2}$ and $V_{3}$ differ significant with their control. Hence we can say with 95 percent level of confidence the variety $\mathrm{V}_{1} \mathrm{~T}_{3}$ loosed significantly much more activity of peroxidase enzyme by at least -17.89 to -17.68 followed by $\mathrm{V}_{5} \mathrm{~T}_{3}-17.70$ to -17.59 however, $\mathrm{V}_{3} \mathrm{~T}_{3}$ recorded at least -8.88 to- 8.25 lowest but significant with their control respectively. The variety $\mathrm{V}_{1}$ more affected by time of high temperature with pressure were found to be superior rather than $V_{5}, V_{4}, V_{2}$ and $V_{3}$ respectively with respect losses of activity of peroxidase enzyme as compare with five varieties of raw soybean seeds.

Table 3:- Specific activity for peroxidase (nM,hydoperoxide/g.protein/min.)

\begin{tabular}{|l|l|l|l|l|l|l|}
\hline Treatments & Control & Processed & d value & Confidence level & \multicolumn{3}{l|}{} \\
\hline V1T1 & 20.81 & 14.07 & -6.740 & -6.843 & to & -6.637 \\
\hline V1T2 & 20.81 & 11.07 & -9.740 & -9.843 & to & -9.637 \\
\hline V1T3 & 20.81 & 3.02 & -17.790 & -17.893 & to & -17.687 \\
\hline V1T4 & 20.81 & 10.55 & -10.260 & -10.363 & to & -10.157 \\
\hline & & & & & & \\
\hline
\end{tabular}




\begin{tabular}{|l|l|l|l|l|l|l|}
\hline V2T1 & 18.25 & 11.71 & -6.540 & -6.550 & to & -6.530 \\
\hline V2T2 & 18.25 & 8.96 & -9.290 & -9.300 & to & -9.280 \\
\hline V2T3 & 18.25 & 8.01 & -10.240 & -10.250 & to & -10.230 \\
\hline V2T4 & 18.25 & 9.55 & -8.700 & -8.710 & to & -8.690 \\
\hline & & & & & & \\
\hline V3T1 & 18.56 & 12.27 & -6.290 & -6.607 & to & -5.973 \\
\hline V3T2 & 18.56 & 11.53 & -7.030 & -7.347 & to & -6.713 \\
\hline V3T3 & 18.56 & 9.99 & -8.570 & -8.887 & to & -8.253 \\
\hline V3T4 & 18.56 & 11.98 & -6.580 & -6.897 & to & -6.263 \\
\hline & & & & & & \\
\hline V4T1 & 19.09 & 12.2 & -6.890 & -6.920 & to & -6.860 \\
\hline V4T2 & 19.09 & 8.44 & -10.650 & -10.680 & to & -10.620 \\
\hline V4T3 & 19.09 & 6.06 & -13.030 & -13.060 & to & -13.000 \\
\hline V4T4 & 19.09 & 10.58 & -8.510 & -8.540 & to & -8.480 \\
\hline & & & & & & \\
\hline V5T1 & 18.65 & 11.54 & -7.110 & -7.161 & to & -7.059 \\
\hline V5T2 & 18.65 & 9.26 & -9.390 & -9.441 & to & -9.339 \\
\hline V5T3 & 18.65 & 1 & -17.650 & -17.701 & to & -17.599 \\
\hline V5T4 & 18.65 & 9.85 & -8.800 & -8.851 & to & -8.749 \\
\hline
\end{tabular}

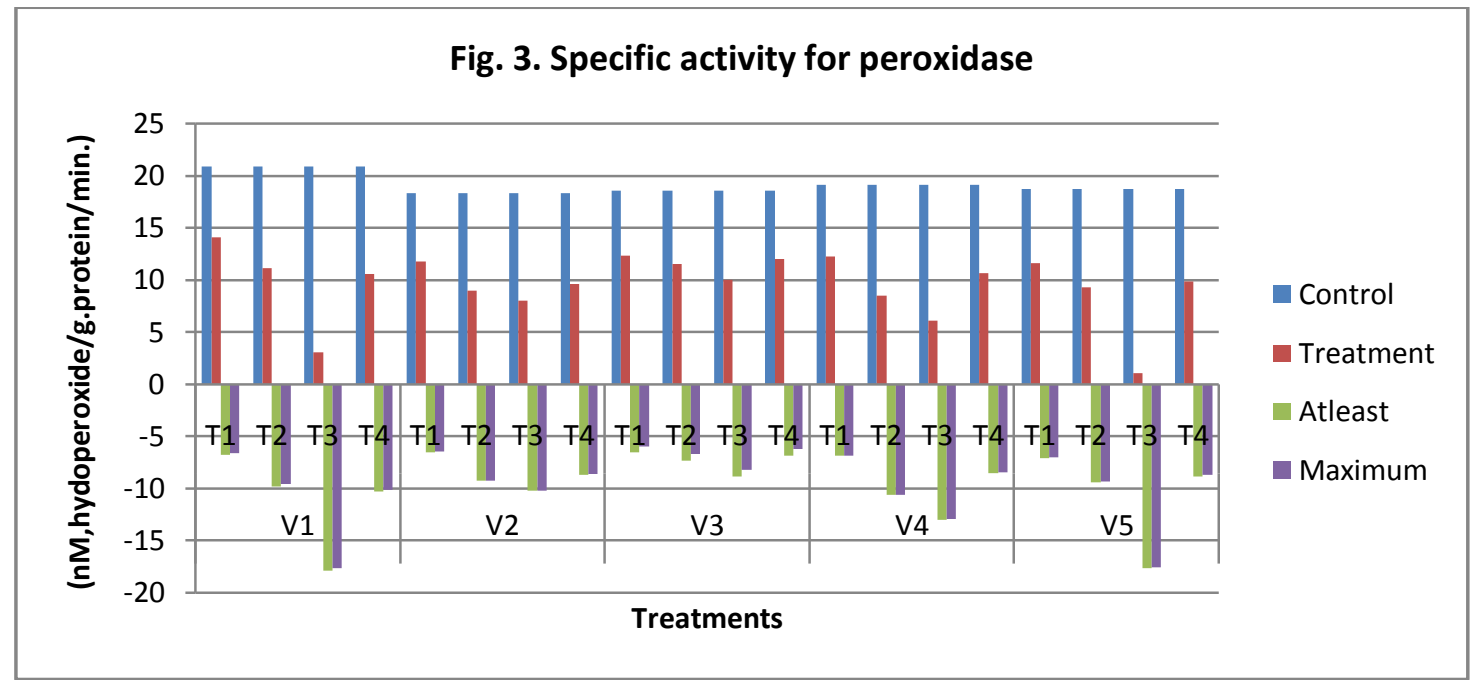

\section{Conclusion:-}

We conclude that variety $\mathrm{V}_{1}$ more effect for trypsin inhibitory activity (TIA) ( $\mu \mathrm{M}$ tyrosine produced gram protein/min) at high temperature rather than $\mathrm{V}_{2}, \mathrm{~V}_{3}, \mathrm{~V}_{4}$ ad $\mathrm{V}_{5}$ with respect to the losses of trypsin inhibitory activity as compare to raw seeds of five varieties. Germination or sprouting process was found better than cooking for 10 min by autoclaved.

The inactivation of lypoxygenase activity show very clearly with 95 percent confidence interval label the thermal processing much more better than germinating process for production of good quality and long storage stability for full fat soy flour, hence variety $V_{1}$ was found highly sensitive for specific activity for lypoxygease enzyme at high temperature among the others as compare to raw seeds.

Inactivation of peroxidase activity required more than $20 \mathrm{~min}$ processing at high temperature. The results are concluded activity of peroxidase enzyme is more stable till the $20 \mathrm{~min}$ autoclaved process as compare trypsin inhibitory activity then lypoxygenase activity reduced proportionally positive to time of autoclaved processing. 


\section{Acknowledgement:-}

The authors highly acknowledged to Dr. O.P. Sharma (HOD) Department of chemistry and Dr.(Smt.) Anjali Bajpai, Dr.S.K. Bajpai, and Dr A.K. Bajpai, Govt. Model Science College(Auto) Jabalpur(MP).

\section{References:-}

1. AACC (2000). Approved methods of the AACC. $10^{\text {th }}$ edition. St. Paul, USA, American Association of Cereal Chemists.

2. AOAC, (2000). Official methods of analysis $\left(17^{\text {th }}\right.$ ed.) Volume I. Association of Official Analytical Chemists, Inc. Maryland, USA. .

3. Axelrod, B., Cheesebrough, T.M. and Laakso, S.(1981). Lipoxygenase from soybean. Methos in Enzymology, $71: 441-451$.

4. Chance, B. and Maehly, A.C. (1955). Enzymatic Assay of Peroxidase (EC 1.11.1.7) from soybean, Methods in enzymology, $2: 773$.

5. Silva, E.D., Teixeira, M. and Franco, T. (2000). Purification of soybean peroxidase (Glycine max L.) by metal affinity partitioning in aqueous two-phase system. J. Chromatog. B-743, 287.

6. Ghaemmaghami, F., Alemzadeh, I. and Motamed, S. (2010). Seed coat soybean peroxidase : Extration and Biocatalytic properties determination. Indian Journal of Chemical engineering, 7(2) : 28-38.

7. Gomori, G. (1955). Methods in enzymology. In : Colowick SP, Kaplan No, editors. Vol. I. New York : Academic Press, p. 138.

8. Gupta,G.K., Sharma S.K., Kumar V. and Ramteke, R. (2014). Effect of purple seed stain disease on physical and biochemical traits of soybean. Soybean Res.12 (1): 77-84.

9. Huisman, J. and Tolman, G.H.(2001). Antinutritional factors in the plant proteins of diets for non-ruminants. Recent Developments in Pig Nutrition, 3, 261-291, Netherlands

10. Igor, A. Butovich and Svetlana, M. Lukyanova (2008). Inhibition of lipoxygenase by linolyl hydroxamic acid: comparative in vitro studies. J. Lipid Res. 49: 1284- 1294.

11. Meriles J.M., Guzman C.A. and Maestri, D.M.(2000) Lypoxygenase activity of soybean genotypes grown in Argentina. Molecules, 5:475- 478.

12. Kakade, M.L., Rackis, J.J., McGhee, J.E. and Puski, G. (1974) Determination of trypsin inhibitor activity of soy products: A collaborative analysis of an improved procedure. American Association of Cereal Chemists, 51, 376-377.

13. Verma K.,Talukdar, A., Shivkumar, M., Kumar B., Lal S.K., Srivastava N., Sapra R.L., Harish G.D. and Girmila, V.(2015). Biochemical screening for trypsin inhibitor factors and morphomolecular characterization of soybean (Glycune max L merr.).Indian J.Gene., 75 (4): 490-495.

14. ley AF, K ühn K, Schewe T,editors (1998). Plant lipoxygenase: structure and mechanism in eicosanoids and related compounds in plants and animals.Portland Press; 1998. p. 69-95.

15. Liener, I.E.(1980). Antinutritional factors as determinants of soybeans quality. In: Frederick, T.C., World Soybean Research Conference II. Westview Press Boulder, Colorado. 703-712.

16. Messina, M. (2004). Nutritional value of soyfood. Ph.D. Thesis Department of Nutrition, Michigam State University, United State of Maerica, pp. 6.

17. Olorode, Omobolanle, O. Idowa Michael, A., Bamgbose, A. and Ayano Adeola, E. (2014). Chemical, phytochemical and functional properties of selected seeds flours. Inter. J. Nutr. Food Sci., 3(6) : 572-578.

18. Rackis, J.J. (1980) Biological active components. Ch. 6, In soybeans chemistry and technology. Volume1Proteins, A.K. Smith and S.J. Circle (ed), p. 158-202. AVI Publishing Co., Inc, Westport, CT.

19. Marenco, R.A., Lopes, N.F. and Moreira, M.A.(1995). Photosynthesis ad leaf lipoxygenase activity in soybean genotypes lacking seeds lipoxygenase isozymes. R. Bras.Fisiol.Veg. 7(1): 21-25.

20. Shivakumar, M.,Verma, K., Talukdar, A.,Srivastava, N., Lal, S.K., Sapra, R.L. and Singh, K.P. (2015). Genetic variability and effect of heat treatment on trypsin inhibitor content in soybean (Glycune max (L) merrill.). Legume Res.,38: 60-65.

21. Temel, R.E. (2003). Lowry protein assay, J. Biol. Chem. $278: 4792$.

22. USDA (1975). Enzyme inactivation tests (frozen vegetables) inspection procedure for the use of USDA inspection. Agril. Mar. Ser.US,Dep.of Ag., Washington DC.

23. Vineet, K., Anita, R. Vimal, P. and Chauhan, G.S.(2005). Changes in lipoxygenase isozymes and trypsin inhibitor activity in soybean during germination at different temperatures, Indore, India.

24. Williams, D.C., Lim, M.H., Chem, A.O., Pongborn, R.M. and Whitaker, J. (1986). Blanching of vegetables for freezing-which indicator enzyme to use. Food Technol. 40(6) : 130-137. 